\title{
Review
}

\section{Mitochondria and Parkinson's Disease: Clinical, Molecular, and Translational Aspects}

\author{
Max Borsche ${ }^{\mathrm{a}, \mathrm{b}}$, Sandro L. Pereira ${ }^{\mathrm{c}}$, Christine Klein ${ }^{\mathrm{a}, *}$ and Anne Grünewald ${ }^{\mathrm{a}, \mathrm{c}}$ \\ ${ }^{a}$ Institute of Neurogenetics, University of Lübeck, Lübeck, Germany \\ ${ }^{\mathrm{b}}$ Department of Neurology, University of Lübeck, Lübeck, Germany \\ ${ }^{\mathrm{c}}$ Luxembourg Centre for Systems Biomedicine, University of Luxembourg, Esch-sur-Alzette, Luxembourg
}

Accepted 20 September 2020

Pre-press 10 October 2020

\begin{abstract}
Mitochondrial dysfunction represents a well-established player in the pathogenesis of both monogenic and idiopathic Parkinson's disease (PD). Initially originating from the observation that mitochondrial toxins cause PD, findings from genetic PD supported a contribution of mitochondrial dysfunction to the disease. Here, proteins encoded by the autosomal recessively inherited PD genes Parkin, PTEN-induced kinase 1 (PINK1), and DJ-1 are involved in mitochondrial pathways. Additional evidence for mitochondrial dysfunction stems from models of autosomal-dominant PD due to mutations in alpha-synuclein (SNCA) and leucine-rich repeat kinase 2 (LRRK2). Moreover, patients harboring alterations in mitochondrial polymerase gamma $(P O L G)$ often exhibit signs of parkinsonism. While some molecular studies suggest that mitochondrial dysfunction is a primary event in PD, others speculate that it is the result of impaired mitochondrial clearance. Most recent research even implicated damage-associated molecular patterns released from non-degraded mitochondria in neuroinflammatory processes in PD. Here, we summarize the manifold literature dealing with mitochondria in the context of PD. Moreover, in light of recent advances in the field of personalized medicine, patient stratification according to the degree of mitochondrial impairment followed by mitochondrial enhancement therapy may hold potential for at least a subset of genetic and idiopathic PD cases. Thus, in the second part of this review, we discuss therapeutic approaches targeting mitochondrial dysfunction with the aim to prevent or delay neurodegeneration in PD.
\end{abstract}

Keywords: Parkinson's disease, mitochondria, mitochondrial dysfunction, Parkin, PINK1, DJ-1, POLG, gene-specific therapy, clinical trial

\section{INTRODUCTION}

The prevalence of Parkinson's disease (PD) has more than doubled over the last two decades, making it the fastest growing of all neurological diseases

\footnotetext{
*Correspondence to: Christine Klein, MD, Institute of Neurogenetics, University of Lübeck, Ratzeburger Allee 160, BMF Building 67, 23538 Lübeck, Germany. Tel.: +49 45131018200 ; Fax: +49 4513101 8204; E-mail: christine.klein@ neuro.uniluebeck.de.
}

[1]. Despite significant advances in deciphering the pathophysiology of PD [2], the etiology remains elusive for the majority of cases.

On the cellular level, an involvement of oxidative stress, lysosomal and mitochondrial dysfunction has been implicated in the pathophysiology of PD [3]. The first evidence that alterations in mitochondrial function may play a decisive role in the pathogenesis of PD date back to the 1980s, when mitochondrial toxins were reported to cause doparesponsive parkinsonism [4]. Subsequently, findings 
from PD genetics supported the link between mitochondria and PD [5]. Here, it has been shown that mutated genes causing monogenic PD encode proteins involved in mitochondrial function and degradation of damaged mitochondria. This review aims to 1) discuss the origin of the link between PD and mitochondria, 2) summarize how pathogenic variants in the PD genes Parkin, PTEN-induced kinase 1 (PINK1) and DJ-1 as well as parkinsonismassociated mutations in mitochondrial Polymerase gamma (POLG) cause mitochondrial impairment, and 3) present how oxidative stress leads to mitochondrial DNA (mtDNA) disintegration in PD. Moreover, 4) we illustrate how mitochondrial damage may cause inflammation in the context of PD. Additionally, 5) we summarize the interaction between mitochondrial and lysosomal pathways as well as the endoplasmic reticulum (ER) with a focus on calcium homeostasis. Finally, 6) we discuss resulting implications for genetic testing and highlight possible therapeutic approaches arising from a potential mitochondrial subtype of PD.

\section{ORIGINS OF THE LINK BETWEEN MITOCHONDRIA AND PD}

First, the so-called "frozen addicts" suggested a contribution of mitochondrial dysfunction to the pathogenesis of PD. In these drug users, living in California in the 1980s, physicians observed that a side product of new synthetic heroin triggered a rapid onset of a distinct form of parkinsonism responsive to levodopa treatment. It turned out that the synthesis process resulted in the unwanted generation of 1-methyl-4-phenyl-1,2,5,6tetrahydropyridine (MPTP), which led to inhibition of the respiratory chain [4]. Of note, a similar observation was published already four years earlier [6]. MPTP is not toxic itself but lipophilic and thus able to enter brain tissue by crossing the blood brain barrier. In the brain, it is processed by monoamine oxidase B (MAO-B) [7] to the toxic cation 1-methyl4-phenylpyridinium (MPP+) [8]. MPP+is selectively taken up by dopaminergic cells [9] and inhibits multiple complexes of the respiratory chain $[3,10]$. The notion that mitochondrial dysfunction plays a role in PD pathogenesis was supported shortly after the description of the "frozen addicts" by the observation of a restricted function of respiratory chain complexes in postmortem brain sections from PD patients [11]. These early findings significantly stimulated PD research in the following years. For example, even today, the injection of MPTP is most commonly used to model PD in mice [12]. However, similar to other animal models of PD, the clinical and pathological characteristics simulated by the MPTP model differ from PD in many ways [13].

Disturbances in respiratory chain complexes are associated with the generation of reactive oxygen species (ROS) suggesting oxidative stress as a pathogenic mechanism in PD related to mitochondrial dysfunction. Highlighting the role of ROS, evidence has arisen that oxidative stress is linked to dopamine metabolism [14]. Later in the present review, we will particularly focus on the aspect of oxidative stress and mtDNA disintegration.

\section{MONOGENIC PD AND MITOCHONDRIAL DYSFUNCTION}

Over the past two decades, intensive research has resulted in significant progress regarding the elucidation of monogenic causes of PD. After the initial description of pathogenic variants in the alphasynuclein gene (SNCA) as of cause PD in 1997 [15], several genes have been identified that are associated with the development of PD signs resembling those of idiopathic PD. These genetic alterations are considered as disease-causing or as genetic risk factors. In particular, the autosomal dominantly inherited genes SNCA, Leucine-rich repeat kinase 2 (LRRK2), and Vacuolar protein sorting-associated protein 35 (VPS35) [16] and the autosomal recessively transmitted genes Parkin, PINK1, and DJ-1 [17] are both well established and validated to cause PD when mutated. In addition, a number of genes have been shown to cause atypical parkinsonism [18].

In the context of autosomal dominantly inherited PD, several links to mitochondrial dysfunction have been described in the past decade. For instance, the protein encoded by the first PD-linked gene SNCA is a component of Lewy bodies [19], which were recently also identified to contain organelles including mitochondria [20]. Alpha-synuclein has been shown to accumulate in mitochondria, interfering with complex I function and increasing mitophagy [21]. Thereby, calcium can trigger alpha-synucleinmediated mitochondrial dysfunction [22, 23]. In keeping with these findings, the $\mathrm{N}$-terminal domain of alpha-synuclein is associated with respiratory chain complex I [24]. Moreover, neuroepithelial stem cells (NESCs) harboring PD-causing SNCA muta- 
tions showed reduced mitochondrial function [25]. In addition, a nonfibrillar, phosphorylated species of alpha-synuclein has been shown to target mitochondria, thereby inducing mitochondrial fragmentation, energy deprivation and mitophagy [26]. The role of alpha-synuclein at the mitochondria-associated endoplasmic membrane (MAM) will be discussed below in a separate section on inter-organellar crosstalk.

There is also evidence for a role of LRRK2 in the regulation of mitochondrial function. Mutations in LRRK2 cause the most common and autosomal dominantly inherited form of monogenic PD clinically indistinguishable from IPD [27, 28]. As described later in this review, Parkin and PINK1 play a well-established role in a common pathway mediating mitophagy, the process of degrading damaged mitochondria. Similarly, LRRK2 is involved in the initiation of mitophagy by regulating mitochondrial motility [3]. Further evidence for an involvement of LRRK2 in mitochondrial clearance comes from our own observation of elevated mtDNA deletion levels specifically in affected $L R R K 2$ mutation carriers, implicating mtDNA integrity as potential penetrance marker for LRRK2-linked PD [29]. Concerning mutations in VPS35, another cause of autosomal dominantly inherited PD [30], there is also evidence for an association with mitochondrial dysfunction. For example, VPS35-mutant fibroblasts exhibited an impaired configuration of complex I of the respiratory chain [31]. In dopaminergic neurons, VPS35 depletion leads to the accumulation of $\alpha$-synuclein and mitochondrial dysfunction [32]. An additional mechanistic link between VPS35 and mitochondria was demonstrated when the fission factor dynaminlike protein (DLP) 1 emerged as interactor of VPS35 [33].

Moreover, the PD-associated protein $\mathrm{CHCHD} 2$ [34] has been found to accumulate in mitochondria under the influence of stress [35]. Further studies will be needed to shed light on its interaction with CHCHD10 [36].

However, the most compelling evidence for a direct link between mitochondria and PD has been established for the autosomal recessively inherited PD genes Parkin, PINK1, and DJ-1, as illustrated by a PubMed search: Combining "Parkinson's disease AND mitochondria" with any of these three gene names results in over 4500 publications in total. Interestingly, patients with genetic alterations in the mitochondrial disease-associated gene POLG also exhibit parkinsonism, albeit a clinically more atypical form.

\section{Parkin-linked PD}

Clinically, biallelic mutations in Parkin cause typical levodopa-responsive PD with early disease onset, slow progression and dystonia as prominent (initial) symptom, while non-motor features like olfactory dysfunction, psychiatric symptoms or cognitive impairment are less frequent compared to IPD [17] (Table 1).

In 1997, an unidentified gene mapping to chromosome 6q25.2-27 was initially linked to an autosomal recessive juvenile form of parkinsonism [37]. Shortly thereafter, the sequence of Parkin was unveiled, with subsequent reports furthering its significance for the etiology of PD [38]. To date, more than 130 different mutations in Parkin have been documented in about 1000 PD patients [17], making it the most prevalent autosomal recessive form of PD [39]. Parkin is an E3 ubiquitin ligase with established neuroprotective activities. Furthermore, Parkin has an extensive array of putative substrates [40], which can be differentially modified either through mono- or poly-ubiquitination with different patterns of ubiquitin lysine linkage. This results in a complex, yet insufficiently characterized array of regulatory nodes associated to this protein. Parkin exerts its function through three independent mechanistic axes [41]: 1) enhanced ubiquitination of toxic substrates to be degraded by the proteasome, 2) regulation of cell death pathways through non-degradative ubiquitin signaling, and 3) regulation of mitochondrial quality control through mitophagy and vesicular transport. Although initial reports failed to detect mitochondrial localization of Parkin [42], it is currently established that this protein is intimately related to the regulation of mitochondrial homeostasis.

Lys-48-polyubiquitinated Parkin substrates are directed to the proteasomal degradation pathway [43], meaning that Parkin deficiency or inactivation can lead to accumulation of diverse noxious substrates that are normally targeted for degradation. A good example of this is PARIS, a repressor of the master regulator of mitochondrial biogenesis and respiration, PGC1- $\alpha$ [44], as will be further explained below. The first indisputable evidence for parkin's involvement in mitochondrial homeostasis arose from the study of Drosophila [45] and mouse [46] parkin $^{-/-}$models. Remarkably, these fly models exhibited degenerative phenotypes, which considerably overlapped with those reported soon thereafter in pink $1^{-/-}$fly models [47-49], exposing a mechanistic link between parkin, pink1 and mitochondrial qual- 
Table 1

Overview of genes particularly associated with mitochondrial dysfunction in Parkinson's disease and $P O L G$ as representative of genetic mitochondrial disease with parkinsonian features

\begin{tabular}{|c|c|c|c|c|}
\hline Type of PD & Additional reading & $\begin{array}{l}\text { Median age of } \\
\text { onset (range) }\end{array}$ & Clinical features & $\begin{array}{l}\text { Frequency and type } \\
\text { of mutations }\end{array}$ \\
\hline PARK-Parkin (PARK2) & $\begin{array}{l}\text { MDSGene } \\
\text { https://www.mdsgene.org/d/1/g/4) } \\
\text { GeneReviews } \\
\text { http://www.ncbi.nlm.nih.gov/ } \\
\text { books/NBK1223/ } \\
\text { OMIM 600116 }\end{array}$ & $31(3-81)$ years* & $\begin{array}{l}\text { Slower disease course, frequent } \\
\text { dystonia (also as presenting } \\
\text { feature), rarely cognitive decline; } \\
\text { Usually responsive to levodopa } \\
\text { treatment. }\end{array}$ & $\begin{array}{l}\text { Relatively common; most common known } \\
\text { cause of early-onset PD. Many private } \\
\text { mutations ( }>100) \text { including }>50 \% \\
\text { deletions and duplications (gene dosage } \\
\text { analysis necessary). Autosomal-recessive } \\
\text { inheritance, heterozygous mutations } \\
\text { possible genetic risk factors for PD. }\end{array}$ \\
\hline PARK-PINK1 (PARK6) & $\begin{array}{l}\text { MDSGene } \\
\text { https://www.mdsgene.org/d/1/g/5 } \\
\text { GeneReviews } \\
\text { http://www.ncbi.nlm.nih.gov/ } \\
\text { books/NBK1223/ } \\
\text { OMIM 605909 }\end{array}$ & 32 (9-67) years* & $\begin{array}{l}\text { Clinically very similar to } \\
\text { PARK-Parkin, commonly with } \\
\text { dystonia, rarely cognitive decline } \\
\text { but possibly higher rate of } \\
\text { psychiatric manifestations. } \\
\text { Atypical signs rare. Usually } \\
\text { responsive to levodopa treatment. }\end{array}$ & $\begin{array}{l}\text { Relatively rare; second most common known } \\
\text { cause of early-onset PD. Private mutations } \\
\text { including rare deletions and duplications } \\
\text { (gene dosage analysis necessary). } \\
\text { Autosomal-recessive inheritance, } \\
\text { heterozygous mutations possible genetic } \\
\text { risk factors for PD. }\end{array}$ \\
\hline PARK-DJ-1 (PARK7) & $\begin{array}{l}\text { MDSGene } \\
\text { https://www.mdsgene.org/d/1/g/3 } \\
\text { GeneReviews } \\
\text { https://www.ncbi.nlm.nih.gov/ } \\
\text { books/NBK1223/ } \\
\text { OMIM 606324 }\end{array}$ & $27(15-40)$ years* & $\begin{array}{l}\text { Early-onset PD, dystonia as common } \\
\text { feature. Usually responsive to } \\
\text { levodopa treatment. }\end{array}$ & $\begin{array}{l}\text { Extremely rare, about } 30 \text { patients with about } \\
20 \text { different disease-causing variants; most } \\
\text { often missense changes, followed by } \\
\text { splice-site mutations and structural } \\
\text { variants and frameshifts. } \\
\text { Autosomal-recessive inheritance. }\end{array}$ \\
\hline$P O L G$ & $\begin{array}{l}\text { GeneReviews } \\
\text { https://www.ncbi.nlm.nih.gov/ } \\
\text { books/NBK26471/ } \\
\text { OMIM } 203700,613662 \\
\quad 607459,157640,258450\end{array}$ & $\begin{array}{l}\text { About } 40 \text { years, in } \\
\text { some families } \\
\text { earlier. }\end{array}$ & $\begin{array}{l}\text { Diverse phenotypic spectrum with } \\
\text { onset from early infancy to late } \\
\text { adulthood; Parkinsonism as the } \\
\text { most frequent movement disorder } \\
\text { feature associated with POLG } \\
\text { mutations; good response to } \\
\text { levodopa. }\end{array}$ & $\begin{array}{l}\text { More than } 300 \text { pathogenic mutations } \\
\text { reported; mtDNA deletions or depletions } \\
\text { as consequence of POLG mutations; no } \\
\text { direct genotype-phenotype correlation; } \\
\text { both autosomal-dominant and -recessive } \\
\text { inheritance reported. }\end{array}$ \\
\hline
\end{tabular}

*Taken from www.mdsgene.org; table according to [17, 144, and 145]; mtDNA, mitochondrial DNA; MDS, Movement Disorder Society; OMIM, Online Mendelian Inheritance in Man; PINK1, PTEN-induced kinase 1; POLG, Polymerase gamma. 
ity control processes which will be further addressed below.

\section{PINK1-linked PD}

Autosomal recessively inherited mutations in PINK1 cause early-onset PD with similar clinical features as described for PD due to biallelic Parkin mutations [17]. However, non-motor symptoms are slightly more frequent in PINK1-compared to Parkin-linked PD [17] (Table 1).

In 2001, a seminal study identified a novel locus for autosomal recessive early-onset parkinsonism at chromosome 1p35-p36 [50], which would later prove to be PINK1 [51]. PINK1 encodes a serine/threonine kinase possessing a mitochondrial translocation sequence, which led to the recognition of the protein's involvement in mitochondrial function [51]. The kinase activity of PINK1 has been shown to be regulated by autophosphorylation on specific sites within the kinase domain (Ser228, Ser402 and Thr257) [52-54]-a process which is, for example, essential for Parkin translocation to the mitochondria upon mitochondrial stress [53] (Fig. 1).

In 2006, a series of reports on pink1-deficient Drosophila models exposed the interaction between pink1 and parkin [47-49]. Pink1-deficient male flies were sterile, exhibited marked degeneration of flight muscles and of dopaminergic neurons, and displayed altered mitochondrial ultrastructure that evidenced malfunction [47-49]. Strikingly, these pink1-related phenotypes were consistently replicated in parkin-deficient flies and could be reversed by overexpression of parkin in pink1-deficient flies, but not the inverse. These studies set the stage for the elucidation of the molecular regulatory pathway through which PINK1 and Parkin jointly act to warrant mitochondrial quality control. The predominant model suggests that PINK1 is constitutively expressed and translocated to mitochondria [51], where it functions as a sensor and tag for mitochondrial depolarization and malfunction [55-57]. Under steady-state conditions, PINK1 is readily imported into mitochondria through the TOM/TIM complex, whereby it is processed by the mitochondrial processing peptidase and cleaved by the PARL protease. The released N-terminal-deleted PINK1 fragment is ubiquitinated and degraded by the proteasome [56]. However, under dysfunctional conditions, such as loss of the mitochondrial membrane potential, this processing of PINK1 is inhibited [55, 58], resulting in its stabilization on the outer mitochondrial membrane where it phosphorylates diverse substrates (Fig. 1). Relevant at this level is the phosphorylation of ubiquitin Ser65 and, particularly, the direct phosphorylation of Parkin on Ser65 in its ubiquitin like domain, which has an allosteric effect [43]. This results in the recruitment and activation of Parkin and initiates the complex process of selective removal of damaged mitochondria through mitophagy [55], which has been thoroughly explained elsewhere [56]. Of note, mutations in the PD-linked kinase LRRK2 interfere with Parkin/PINK1-mediated mitophagy in a kinase activity-dependent manner [59] (Fig. 1). Further linking LRRK2 mutations and impaired mitophagy, a recent study demonstrated a Parkin and PINK1dependent accumulation of RAB10 [60].

Besides mitophagy, the mitochondrial quality control program encompasses other mechanisms for the specific removal of localized damaged mitochondrial components. This is accomplished by means of mitochondrial-derived vesicles (MDVs), a particular type of vesicular trafficking [61]. MDVs can be generated as a response to stress [62], and can incorporate damaged cargo such as oxidized proteins which might then be eliminated through lysosomal degradation [3, 61]. Here again PINK1 and Parkin seem to serve as instrumental factors for the formation of MDVs [63] (Fig. 1). Moreover, the outer mitochondrial membrane protein Miro1, which links mitochondria to microtubule motor proteins during transport, is also a target of the Parkin/PINK1 pathway. Miro1 is degraded during the early stages of mitophagy thereby preventing further movement of dysfunctional mitochondria [64] (Fig. 1). In addition, Miro1 was shown to interact with LRRK2, a function that is hampered by the presence of pathogenic mutations, leading to reduced mitophagy and neurodegeneration [65].

The mechanisms through which PINK1 regulates mitochondrial homeostasis are not restricted to the aforementioned quality control process. Under steady-state conditions, PINK1 patientderived fibroblasts and neurons display diminished complex I activity. This dysfunction was correlated to a specific loss of phosphorylation of serine-250 in the complex I subunit NdufA10 secondary to PINK1 deficiency [66] (Fig. 1). This is a good example of the complex and multifaceted regulatory process exerted by PINK1, and exposes its diverse range of actions under steady-state and stress conditions.

Although mitophagy represents a well-established mechanism in Parkin/PINK1-dependent PD, evidence for its role in PD in general is limited. 


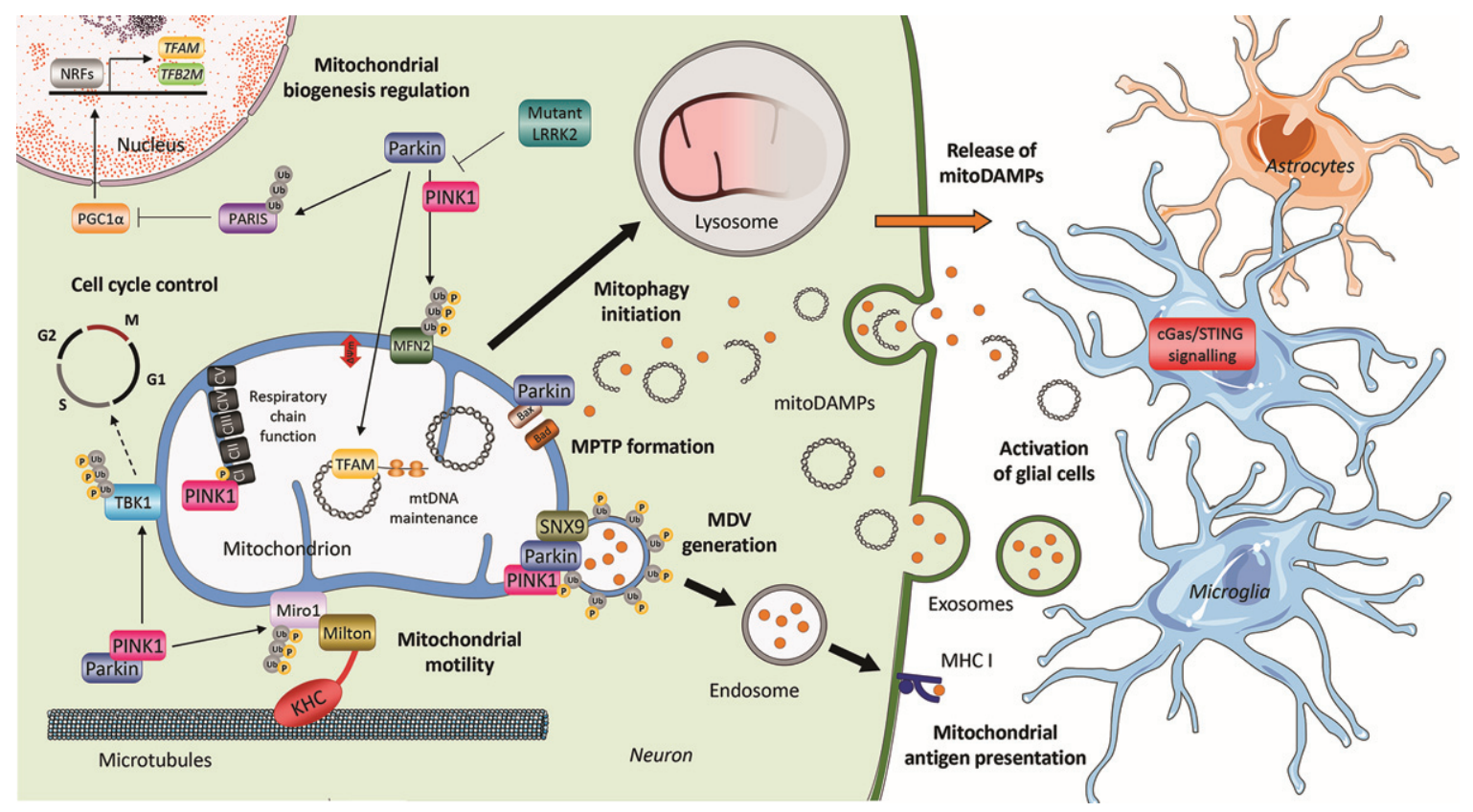

Fig. 1. Involvement of PINK1 and Parkin in mitochondrial processes. The most investigated function of PTEN-induced putative kinase 1 (PINK1) and Parkin is the initiation of mitophagy. A loss in membrane potential triggers the PINK1-mediated recruitment of the E3 ubiquitin ligase Parkin to mitochondria. At the outer mitochondrial membrane, Parkin ubiquitinates proteins thereby tagging dysfunctional mitochondria for lysosomal degradation. This process can be inhibited by mutant LRRK2. In addition, both PINK1 and Parkin, in conjunction with Snx9, are involved in the formation of mitochondria-derived vesicles (MDVs), which can transport cargo such as mitochondrial damageassociated molecular patterns (mitoDAMPs). After engulfment of MDVs by endosomes, mitochondrial antigens are transported to the plasma membrane, where they are presented on histocompatibility complex class I (MHC I) molecules. MitoDAMPs can also be released from mitochondria trough the mitochondrial permeability transition pore (MPTP), which is formed under the control of Parkin - an interaction partner of the pro-apoptotic protein BCL2-antagonist/killer (BAK). In a PINK1- or Parkin-deficient environment, mitoDAMPs accumulate extracellularly and trigger cyclic GMP-AMP synthase/stimulator of interferon genes (cGas/STING) inflammatory signaling. However, the exact release mechanisms of mitoDAMPs and their impact on the interplay of neuronal and glial cells remain to be studied in human-derived PD models. In addition to its role in mitophagy, Parkin can modulate mitochondrial biogenesis by ubiquitination of the Peroxisome proliferatoractivated receptor gamma coactivator 1-alpha (PGC1- $\alpha$ ) inhibitor PARIS or by direct interaction with the mitochondrial transcription factor A (TFAM) at the mtDNA. Moreover, Parkin influences cell cycle progression via its ubiquitination target TANK-binding kinase 1 (TBK1). By controlling the degradation of the microtubule adaptor protein Miro1, which links kinesin heavy chain (KHC) to mitochondria, PINK1 and Parkin regulate mitochondrial arrest as a prerequisite for mitochondrial clearance. Finally, there is also evidence for a direct interaction between PINK1 and respiratory chain complex I. Accordingly, PINK1 influences the activity of complex I by phosphorylation of its subunit NADH:ubiquinone oxidoreductase subunit A10 (NdufA10). The online image library Servier Medical Art (http://smart.servier.com/) was used to create this Figure, which is partially based on our previous review [3].

Decreased mitophagy was demonstrated in IPD in a few studies on IPD fibroblasts and induced pluripotent stem cell (iPSC)-derived neurons [3]; however, the majority of results concerning genetic PD still stem from overexpression models [67]. Thus, the endogenous role of Parkin and PINK1 will require further investigation. Moreover, it is currently unknown how the genetic lack of these proteins specifically causes dopaminergic neurodegeneration. Given the ubiquitous expression of Parkin and PINK1 throughout the body, the absence of more wide-spread pathology also remains puzzling. These important research questions should be addressed in future studies.

\section{DJ-1-linked PD}

Mutations in the gene encoding the protein deglycase DJ-1 cause autosomal recessive PD [68] (Table 1), but are less common than mutations in Parkin or PINK1. Regarding DJ-1, several mechanistic links to impaired mitochondrial function have been described. First, the absence of $D J-1$ alters mitochondrial morphology [69]. Moreover, in line with the already mentioned role as ROS scavenger in $\mathrm{PD}$, an association between dopamine oxidation, mitochondrial, and lysosomal dysfunction was demonstrated in iPSC-derived neurons with mutations or depletion of $D J-1$ in human and mice, 
respectively [70]. In keeping with this finding, also alterations in respiratory chain complex integrity were described in DJ-1-depleted neuronal cells [71].

\section{POLG-related parkinsonism}

In 2001, a preliminary study reported an association between POLG mutations and progressive external ophthalmoplegia (PEO) in three different Belgian families [72]. Thereafter, POLG mutations have been linked to an extraordinarily large set of disorders comprising a mitochondrial component, such as Alpers-Huttenlocher syndrome and, remarkably, recessively and dominantly inherited parkinsonism [73-75]. Interestingly, rare polymorphic variants of $P O L G$ have been suggested to pose a risk factor for IPD [76-78]. As discussed in the following, this hypothesis is supported by the observation of enhanced somatic variability in the mitochondrial genome of IPD patients. POLG is the only known mammalian polymerase present in mitochondria, where it integrates the molecular complex responsible for mtDNA polymerization [79]. The functional complex is composed of a catalytic subunit encoded by the nuclear gene $P O L G$ and a homodimer accessory protein encoded by the POLG2 gene [75]. Adding to its polymerase activity, POLG additionally encompasses exonuclease function (which assures fidelity of mtDNA replication [80]) and 5' deoxyribose phosphate lyase activity. The latter function is instrumental for the base excision repair process necessary to correct oxidative damage to mtDNA [79, 81]. Overall, the combination of these three enzymatic competencies place POLG as a key player in the maintenance of mtDNA homeostasis. Therefore, it is not surprising that mutations, which compromise POLG function can lead to mitochondria-associated disorders including parkinsonism. However, it is worth mentioning that $P O L G$-associated Alpers disease does not represent the only mitochondrial disorder including parkinsonism in its clinical spectrum. For instance, parkinsonism in combination with PEO has also been reported in patients with mutations in $T W N K[82,83]$.

\section{OXIDATIVE STRESS AND MTDNA DISINTEGRATION IN PD}

As summarized in the previous sections, multiple lines of evidence point towards a role of oxidative stress in the pathogenesis of PD. In addition to toxininduced or primary respiratory chain dysfunction, the auto-oxidation of dopamine can generate free radicals and active quinones [84]. These ROS have the capacity to damage the mitochondrial genome, causing single- and double-strand breaks [85]. The 16,569 bp-long circular mtDNA codes for few but critical subunits of the respiratory chain complexes I, III, $\mathrm{IV}$, and $\mathrm{V}$. When nicks in the mtDNA are repaired inefficiently, mtDNA point and deletion mutations develop [86]. To protect the mtDNA from oxidative insults, it is packaged in nucleoids by the mitochondrial transcription factor A (TFAM) [87]. By contrast, in dopaminergic neurons from IPD patients, TFAM deficiency has been observed [88, 89], suggesting an enhanced exposure of the mitochondrial genome to ROS.

Transmitochondrial cytoplasmic hybrid (or short cybrid) studies first implicated mtDNA alterations in the pathogenesis of PD. In these experiments, cybrids were created by fusing mature platelets (which naturally lack nuclei) from PD patients with mtDNA-depleted control cells. Introducing patient mtDNA into a control nuclear background sufficed to recapitulate PD-associated mitochondrial phenotypes in the receiving cells [3]. While there is currently no evidence to suggest a role for inherited mtDNA mutations in PD [3], somatic alterations in the mitochondrial genome are likely part of the disease process [90]. Investigating the mitochondrial genome in single postmortem substantia nigra neurons revealed mtDNA copy number depletion and an accumulation of major arc deletions in IPD patients $[88,91,92]$. Moreover, polygenic risk score analyses of whole exome sequences from large IPD cohorts showed increased genetic variation in the mtDNA maintenance pathway [93].

With regard to genetic PD, an additional area of action of Parkin, besides the regulation of mitophagy, lies in the control of mitochondrial biogenesis. A series of studies in mice, drosophila and cell lines showed that the degradation of PARIS, a repressor of PPARGC1A expression, is mediated by Parkin. In this manner, Parkin controls the PGC- $1 \alpha$-induced transcription of nuclear-encoded mitochondrial proteins $[44,94,95]$. However, this finding still awaits confirmation in endogenous PD patient-derived cells. In addition, there is evidence that Parkin's mitochondrial biogenesis-modulating effect extends to the mitochondrial genome. As PGC- $1 \alpha$ was identified as an interactor of the mitochondrial transcription factor A (TFAM) [96], Parkin could convey its action on the mitochondrial genome in an indirect fashion. In addition, in vivo and in vitro immunopre- 
cipitation analyses identified a direct association of Parkin with the mitochondrial genome and TFAM [97, 98]. By binding to the transcription factor in the mitochondrial D-loop region, Parkin may catalyze (multiple) mono-ubiquitylation [99] of TFAM thereby modulating mtDNA gene expression. Further supporting an involvement of Parkin in mtDNA maintenance, crossing parkin knockout mice with "mutator" mice that harbor a proof reading-deficient version of mitochondrial polg revealed 1) an increase in pathogenic mtDNA mutations, 2) enhanced loss of nigral tyrosine hydroxylase-positive neurons, and 3) motor deficits in the double-mutant animals [100]. These results highlight the protective action of Parkin against mtDNA mutagenic stress -a role which is likely intertwined with the protein's newly identified function in inflammatory signaling. Inflammation triggered by mitochondrial damage associated molecular patterns (DAMPs) as emerging topic in PD research will be discussed in more detail in the following section.

\section{MITOCHONDRIAL DAMAGE-INDUCED INFLAMMATION IN PD}

First results suggesting a link between TFAM shedding, mtDNA release and inflammation came from fundamental studies outside of PD research. In mouse embryonic fibroblasts (MEFs), a heterozygous tfam knockout was employed to genetically induce mtDNA stress [101]. Aberrant packaging of the mitochondrial genome due to tfam deficiency led to the escape of mtDNA from the mitochondria. In the cytosol, mtDNA can act as DAMP promoting cGAS/STING inflammatory signaling [101]. During apoptosis, mitochondrial DAMPs can be released through the mitochondrial permeability transition pore. The formation of BAK/BAX [102] or VDAC macropores [103] at the outer mitochondrial membrane has been shown to facilitate mitochondrial herniation and subsequent mtDNA efflux. Interestingly, the PD protein Parkin can ubiquitinate BAK thereby suppressing pore formation [104], cytochrome c release and consequent apoptosis induction $[105,106]$ to ensure efficient clearance of damaged mitochondria, which could otherwise trigger inflammation. A specific role for Parkin and PINK1 in mitochondrial damage-induced inflammation was further supported by a recent study in the above-mentioned parkin knockout "mutator" mouse model. The accumulation of mtDNA alter- ations in the parkin null background, was shown to increase the serum levels of circulating cell-free mtDNA (ccf mtDNA) and of various cytokines. By contrast, depleting stimulator of interferon genes (STING), which regulates the activation of the DNA inflammasome, sufficed to rescue the degeneration of dopaminergic neurons and a motor impairment previously observed in these animals, suggesting that these phenotypes are the result of inflammatory processes [107]. In a trial experiment as part of this study, we could also show upregulated inflammatory profiles in a small number of PD patients with Parkin mutations [107]. Moreover, Parkin/PINK1 have been shown to modulate cell cycle progression via the downstream target of the cyclic GMP-AMP synthase (cGAS)/STING pathway, TANK-binding kinase 1 (TBK1), at damaged mitochondria. Mitochondrially localized TBK1 is sequestered by Parkin/PINK1 during mitophagy, leading to a block in mitosis. By contrast, loss of Parkin or PINK1 accelerated cellular proliferation in mice [108]. While also NOD-, LRRand pyrin domain-containing protein 3 (NLRP3) has been identified as a target of cGas/STING signaling [109], the inflammasome can equally be activated directly by mitochondrial dysfunction and elevated ROS [110]. Treatment of lipopolysaccharide (LPS)-primed mouse microglia with the mitochondrial complex I inhibitor rotenone induced NLRP3 activation, ASC (apoptosis-associated specklike protein containing a CARD domain) speck formation and pro-interleukin- $1 \beta$ processing in a concentration-dependent manner [111]. Moreover, enhanced Parkin-mediated ER-mitochondrial tethering and subsequent mitochondrial calcium overload [112] as well as blockage of mitophagy [113] have been reported to trigger NLRP3 inflammasome activation.

In addition to their role in innate immunity, Parkin and PINK1 may also be involved in the control of the adaptive immune response. In mice lacking parkin or pink1, treatment with the bacteria-derived endotoxin LPS [114] or an intestinal infection with gram-negative bacteria [115] induced the formation of MDVs [63], which transport mitochondrial antigens to the plasma membrane, where they are presented on major histocompatibility complex class I (MHC I) molecules [114, 115]. Both processes, MDV induction and mitochondrial antigen presentation (mitAP), are depending on Sorting nexin 9 (Snx9), the cellular abundance of which is regulated by Parkin in a proteasome-dependent manner [114]. Taken together, these findings suggest that Parkin and 
PINK1 are critically involved in the orchestration of mitophagy induction, immune surveillance and cell cycle control in the context of PD.

\section{CROSSTALK BETWEEN MITOCHONDRIA, LYSOSOMES AND ER AND ITS IMPACT ON CALCIUM HOMEOSTASIS}

Multiple lines of evidence suggest that impaired lysosomal degradation causes an accumulation of dysfunctional mitochondria in PD [3]. Mutations in LRRK2 [116] and SNCA [117] have been demonstrated to interfere with lysosomal pathways. Furthermore, in DJ-1-mutant iPSC-derived neurons, mitochondrial stress was shown to trigger oxidized dopamine accumulation, which in turn led to lysosomal dysfunction, and eventually the accumulation of alpha-synuclein [70].

In addition to the crosstalk between lysosomes and mitochondria, the ER is involved in the interorganellar communication in PD. Alterations of the MAM have been described in different PD models [118]. Exemplarily, alpha-synuclein can be found at the MAM, and pathogenic mutations in SNCA lead to increased mitochondrial fragmentation [119].

Furthermore, calcium homeostasis depends on a well-orchestrated signalling between mitochondria, the lysosome and the ER. In SNCA overexpression models and patient-derived neurons with a triplication mutation, a reduced connection between ER and mitochondria leads to a calcium-dependent decrease in ATP production [120]. However, also Parkin [121], PINK1 and LRRK2 [122], as well as DJ-1 [123] may function in calcium-related pathways.

Emphasizing the role of calcium homeostasis in $\mathrm{PD}$, research demonstrated that isradipine, a calcium channel antagonist, protects dopaminergic neurons [124] by lowering mitochondrial oxidative stress and by reducing mitochondrial turn over and mass [125].

\section{IMPLICATIONS FOR GENETIC TESTING AND POTENTIAL THERAPEUTIC OPTIONS TO AMELIORATE MITOCHONDRIAL FUNCTION IN PD}

Currently, only genetic testing allows identifying patients with probable mitochondrial dysfunction by detection of variants in genes associated with mitochondrial pathways. Nevertheless, at present, only a minority of PD patients undergo genetic testing.
A variety of drugs are used in clinical practice to treat PD, mostly by increasing dopamine levels in the midbrain [126]. However, these approaches only allow for symptomatic treatment, and no neuroprotective effect has been demonstrated with any of the drugs approved to date. Such disease-modifying treatment options are urgently needed as neurodegeneration progresses during the disease course, and symptomatic treatment is not able to prevent severe disability and a significant decrease in the quality of life in later disease stages [127].

Various therapeutic approaches focus on a possible mitochondrial etiology of PD: First, several approaches target the presence of ROS. Although positive effects were observed with various substances in vitro and in vivo in animal models, only the antioxidant substance MitoQ that was reported to protect dopaminergic neurons in 6-OHDA-treated mice [128] reached the testing in clinical trials. Unfortunately, there was no evidence for neuroprotection in PD patients [129].

Second, approaches with mitochondrial enhancers, i.e., substances that generally improve the function of mitochondria, were investigated. Particularly noteworthy in this context are studies in which PD patients were treated with coenzyme Q10 in randomized double-blinded trials [130]. However, no effect of coenzyme Q10 administration on neuroprotection was demonstrated in genetically non-stratified patients. Thus, current approaches are based on the assumption that only a subset of PD patients, namely such suffering from a "mitochondrial form of PD", may benefit from therapy with coenzyme Q10. For this, patients with autosomal recessively inherited PD due to mutations in Parkin and PINKI could serve as "positive controls". A current clinical investigatorinitiated study based on this principle divides IPD patients using a genomic approach into patients with high and low probability of mitochondrial dysfunction due to the presence of a polygenic risk score composed of mitochondrially associated single nucleotide polymorphisms (SNPs) [131]. Another potential mitochondrial enhancer is vitamin $\mathrm{K} 2$. This substance represents, as well as Coenzyme Q10, a dietary supplement. In Drosophila, vitamin K2 has a strong effect on rescuing motor disturbances in pinkl knockout flies [132]. However, studies failed to demonstrate a role for this compound as an electron carrier in mammalian cells [133, 134].

Besides the mentioned established "mitochondrial enhancers", there are novel compounds that have the potential to ameliorate mitochondrial function in PD 
patients. For example, a study testing the potential of the neo-substrate kinetin triphosphate (KTP) demonstrated an increase in the kinase activity of mutant PINK1 in cell culture experiments [135], warranting further tests in PINK1 animal models.

Third, selective MAO-B inhibitors like selegiline and rasagiline represent a group of drugs approved for PD treatment, which show possible evidence for a neuroprotective effect. As described earlier, MAO-B is responsible for the processing of MPTP to $\mathrm{MPP}+$, and, therefore, inhibition of this enzyme might reduce oxidative stress. Early after the description of selegiline, findings from animal models suggested a neuroprotective effect $[7,136]$ and a clinical trial was initiated investigating the effects of selegiline as well as of tocopherol (vitamin E). Here, the so-called DATATOP study suggested a disease-modifying effect of selegiline but not of tocopherol in early stages of PD [137]. However, as selegiline also exhibited symptomatic effects increasing levodopa levels, its neuroprotective effect was questioned. Later, the ADAGIO trial investigated the newer MAO-B inhibitor rasagiline and suggested neuroprotective features in low-dose administration. Surprisingly, this effect was absent at a higher dose [138]. Together, the disease-modifying effect of selective MAO-B inhibitors remains controversial [139]. Furthermore, targeting the interplay between mitochondrial pathways and calcium homeostasis, a clinical trial investigated the calcium channel antagonist isradipine. However, no beneficial effects on motor and non-motor features of PD could be observed [140].

In the context of monogenic PD, the function of the encoded proteins provides a potential starting point for gene-specific therapies [141]. Finally, new treatment options might result from the currently discovered mechanistic relationship between (monogenic) PD and inflammation [107]. In keeping with this notion, the intake of ibuprofen was found to reduce the risk of developing PD [142, 143]. However, further clarification is needed whether inflammation contributes to neurodegeneration in $\mathrm{PD}$, or is instead a consequence of neuronal loss.

\section{CONCLUSION AND OUTLOOK}

Mitochondrial dysfunction represents a wellestablished mechanism in the pathogenesis of both idiopathic as well as monogenic PD. In recent years, investigating monogenic PD has decisively contributed to the clarification of impaired mitochondrial pathways in the sporadic disease. In light of the manifold literature on this topic, it is tempting to speculate that several of the above-mentioned PD proteins form a pathophysiological network surrounding mitochondria. Alterations at any point of this network may contribute to the disease, although the exact mechanisms orchestrating this interplay are still not fully understood.

Despite our advances in basic PD research, clinical trials targeting mitochondrial dysfunction and oxidative stress have not demonstrated significant beneficial effects to date. Of note, however, patients have not yet been stratified according to the etiology of disease in previous trials. In the meantime, different etiologic subtypes of PD have emerged. Stratification approaches, according to such specific subtypes of the disease, are currently being developed and incorporated into trial designs [131].

Most recently, a link between immunologic alterations and mitochondrial dysfunction in autosomal recessively inherited monogenic $\mathrm{PD}$ has been demonstrated [107]. However, evidence that inflammation causes neurodegeneration is limited thus far, and the role of immunity in PD needs further elucidation. Regarding monogenic PD in general, first gene-specific therapies allowing personalized treatment are already undergoing clinical trials. Together, further in-depth investigation along with biomarker establishment of a "mitochondrial subtype" of PD represents a promising approach to arrive at a more individualized treatment even of IPD patients. In the future, continuous efforts in both basic and clinical research with a fast translation of new insights into clinical practice have the potential to lead to new therapeutic approaches in "mitochondrial PD".

\section{ACKNOWLEDGMENTS}

CK is supported by SysMedPD (European Union's Horizon 2020 research and innovation program under grant agreement 668738). CK and AG are supported by the German Research Foundation (FOR2488, GR 3731/5-1). AG received funding from the Luxembourg National Research Fund (ATTRACT career development grant, FNR9631103; INTER grant, FNR11250962).

\section{CONFLICT OF INTEREST}

CK serves as medical advisor for genetic testing reports in the fields of movement disorders and dementia, excluding Parkinson's disease, for Cento- 
gene. MB, SLR and AG have no competing interests to declare.

\section{REFERENCES}

[1] GBD 2016 Parkinson's Disease Collaborators (2018) Global, regional, and national burden of Parkinson's disease, 1990-2016: A systematic analysis for the Global Burden of Disease Study 2016. Lancet Neurol 17, 939-953.

[2] Obeso JA, Stamelou M, Goetz CG, Poewe W, Lang AE, Weintraub D, Burn D, Halliday GM, Bezard E, Przedborski S, Lehericy S, Brooks DJ, Rothwell JC, Hallett M, DeLong MR, Marras C, Tanner CM, Ross GW, Langston JW, Klein C, Bonifati V, Jankovic J, Lozano AM, Deuschl G, Bergman H, Tolosa E, Rodriguez-Violante M, Fahn S, Postuma RB, Berg D, Marek K, Standaert DG, Surmeier DJ, Olanow CW, Kordower JH, Calabresi P, Schapira AHV, Stoessl AJ (2017) Past, present, and future of Parkinson's disease: A special essay on the 200th Anniversary of the Shaking Palsy. Mov Disord 32, 1264-1310.

[3] Grunewald A, Kumar KR, Sue CM (2019) New insights into the complex role of mitochondria in Parkinson's disease. Prog Neurobiol 177, 73-93.

[4] Langston JW, Ballard P, Tetrud JW, Irwin I (1983) Chronic Parkinsonism in humans due to a product of meperidineanalog synthesis. Science 219, 979-980.

[5] Reed X, Bandres-Ciga S, Blauwendraat C, Cookson MR (2019) The role of monogenic genes in idiopathic Parkinson's disease. Neurobiol Dis 124, 230-239.

[6] Davis GC, Williams AC, Markey SP, Ebert MH, Caine ED, Reichert CM, Kopin IJ (1979) Chronic Parkinsonism secondary to intravenous injection of meperidine analogues. Psychiatry Res 1, 249-254.

[7] Heikkila RE, Manzino L, Cabbat FS, Duvoisin RC (1984) Protection against the dopaminergic neurotoxicity of 1-methyl-4-phenyl-1,2,5,6-tetrahydropyridine by monoamine oxidase inhibitors. Nature 311, 467-469.

[8] Langston JW, Irwin I, Langston EB, Forno LS (1984) 1Methyl-4-phenylpyridinium ion (MPP+): Identification of a metabolite of MPTP, a toxin selective to the substantia nigra. Neurosci Lett 48, 87-92.

[9] Storch A, Ludolph AC, Schwarz J (2004) Dopamine transporter: Involvement in selective dopaminergic neurotoxicity and degeneration. J Neural Transm (Vienna) 111, 1267-1286.

[10] Desai VG, Feuers RJ, Hart RW, Ali SF (1996) MPP(+)induced neurotoxicity in mouse is age-dependent: Evidenced by the selective inhibition of complexes of electron transport. Brain Res 715, 1-8.

[11] Schapira AH, Cooper JM, Dexter D, Jenner P, Clark JB, Marsden CD (1989) Mitochondrial complex I deficiency in Parkinson's disease. Lancet 1, 1269.

[12] Langston JW (2017) The MPTP story. J Parkinsons Dis 7, S11-S19.

[13] Vingill S, Connor-Robson N, Wade-Martins R (2018) Are rodent models of Parkinson's disease behaving as they should? Behav Brain Res 352, 133-141.

[14] Blesa J, Trigo-Damas I, Quiroga-Varela A, Jackson-Lewis VR (2015) Oxidative stress and Parkinson's disease. Front Neuroanat 9, 91.

[15] Polymeropoulos MH, Lavedan C, Leroy E, Ide SE, Dehejia A, Dutra A, Pike B, Root H, Rubenstein J, Boyer R, Stenroos ES, Chandrasekharappa S, Athanassiadou A, Papapetropoulos T, Johnson WG, Lazzarini AM, Duvoisin
RC, Di Iorio G, Golbe LI, Nussbaum RL (1997) Mutation in the alpha-synuclein gene identified in families with Parkinson's disease. Science 276, 2045-2047.

[16] Trinh J, Zeldenrust FMJ, Huang J, Kasten M, Schaake S, Petkovic S, Madoev H, Grunewald A, Almuammar S, Konig IR, Lill CM, Lohmann K, Klein C, Marras C (2018) Genotype-phenotype relations for the Parkinson's disease genes SNCA, LRRK2, VPS35: MDSGene systematic review. Mov Disord 33, 1857-1870.

[17] Kasten M, Hartmann C, Hampf J, Schaake S, Westenberger A, Vollstedt EJ, Balck A, Domingo A, Vulinovic F, Dulovic M, Zorn I, Madoev H, Zehnle H, Lembeck CM, Schawe L, Reginold J, Huang J, Konig IR, Bertram L, Marras C, Lohmann K, Lill CM, Klein C (2018) Genotypephenotype relations for the Parkinson's disease genes Parkin, PINK1, DJ1: MDSGene systematic review. Mov Disord 33, 730-741.

[18] Marras C, Lang A, van de Warrenburg BP, Sue CM, Tabrizi SJ, Bertram L, Mercimek-Mahmutoglu S, EbrahimiFakhari D, Warner TT, Durr A, Assmann B, Lohmann K, Kostic V, Klein C (2016) Nomenclature of genetic movement disorders: Recommendations of the International Parkinson and Movement Disorder Society Task Force. Mov Disord 31, 436-457.

[19] Spillantini MG, Schmidt ML, Lee VM, Trojanowski JQ, Jakes R, Goedert M (1997) Alpha-synuclein in Lewy bodies. Nature 388, 839-840.

[20] Shahmoradian SH, Lewis AJ, Genoud C, Hench J, Moors TE, Navarro PP, Castano-Diez D, Schweighauser G, GraffMeyer A, Goldie KN, Sutterlin R, Huisman E, Ingrassia A, Gier Y, Rozemuller AJM, Wang J, Paepe A, Erny J, Staempfli A, Hoernschemeyer J, Grosseruschkamp F, Niedieker D, El-Mashtoly SF, Quadri M, Van IWFJ, Bonifati V, Gerwert K, Bohrmann B, Frank S, Britschgi M, Stahlberg H, Van de Berg WDJ, Lauer ME (2019) Lewy pathology in Parkinson's disease consists of crowded organelles and lipid membranes. Nat Neurosci 22, 10991109.

[21] Chinta SJ, Mallajosyula JK, Rane A, Andersen JK (2010) Mitochondrial alpha-synuclein accumulation impairs complex I function in dopaminergic neurons and results in increased mitophagy in vivo. Neurosci Lett 486, 235-239.

[22] Luth ES, Stavrovskaya IG, Bartels T, Kristal BS, Selkoe DJ (2014) Soluble, prefibrillar alpha-synuclein oligomers promote complex I-dependent, $\mathrm{Ca} 2+$-induced mitochondrial dysfunction. J Biol Chem 289, 21490-21507.

[23] Parihar MS, Parihar A, Fujita M, Hashimoto M, Ghafourifar P (2008) Mitochondrial association of alpha-synuclein causes oxidative stress. Cell Mol Life Sci 65, 1272-1284.

[24] Devi L, Raghavendran V, Prabhu BM, Avadhani NG, Anandatheerthavarada HK (2008) Mitochondrial import and accumulation of alpha-synuclein impair complex I in human dopaminergic neuronal cultures and Parkinson disease brain. J Biol Chem 283, 9089-9100.

[25] Arias-Fuenzalida J, Jarazo J, Qing X, Walter J, GomezGiro G, Nickels SL, Zaehres H, Scholer HR, Schwamborn JC (2017) FACS-assisted CRISPR-Cas9 genome editing facilitates Parkinson's disease modeling. Stem Cell Reports 9, 1423-1431.

[26] Grassi D, Howard S, Zhou M, Diaz-Perez N, Urban NT, Guerrero-Given D, Kamasawa N, Volpicelli-Daley LA, LoGrasso P, Lasmezas CI (2018) Identification of a highly neurotoxic alpha-synuclein species inducing mitochondrial damage and mitophagy in Parkinson's disease. Proc Natl Acad Sci U S A 115, E2634-E2643. 
[27] Paisan-Ruiz C, Jain S, Evans EW, Gilks WP, Simon J, van der Brug M, Lopez de Munain A, Aparicio S, Gil AM, Khan N, Johnson J, Martinez JR, Nicholl D, Marti Carrera I, Pena AS, de Silva R, Lees A, Marti-Masso JF, Perez-Tur J, Wood NW, Singleton AB (2004) Cloning of the gene containing mutations that cause PARK8-linked Parkinson's disease. Neuron 44, 595-600.

[28] Zimprich A, Biskup S, Leitner P, Lichtner P, Farrer M, Lincoln S, Kachergus J, Hulihan M, Uitti RJ, Calne DB, Stoessl AJ, Pfeiffer RF, Patenge N, Carbajal IC, Vieregge P, Asmus F, Muller-Myhsok B, Dickson DW, Meitinger T, Strom TM, Wszolek ZK, Gasser T (2004) Mutations in LRRK2 cause autosomal-dominant parkinsonism with pleomorphic pathology. Neuron 44, 601-607.

[29] Ouzren N, Delcambre S, Ghelfi J, Seibler P, Farrer MJ, Konig IR, Aasly JO, Trinh J, Klein C, Grunewald A (2019) Mitochondrial DNA deletions discriminate affected from unaffected LRRK2 mutation carriers. Ann Neurol 86, 324326.

[30] Zimprich A, Benet-Pages A, Struhal W, Graf E, Eck SH, Offman MN, Haubenberger D, Spielberger S, Schulte EC, Lichtner P, Rossle SC, Klopp N, Wolf E, Seppi K, Pirker W, Presslauer S, Mollenhauer B, Katzenschlager R, Foki T, Hotzy C, Reinthaler E, Harutyunyan A, Kralovics R, Peters A, Zimprich F, Brucke T, Poewe W, Auff E, Trenkwalder C, Rost B, Ransmayr G, Winkelmann J, Meitinger T, Strom TM (2011) A mutation in VPS35, encoding a subunit of the retromer complex, causes lateonset Parkinson disease. Am J Hum Genet 89, 168-175.

[31] Zhou L, Wang W, Hoppel C, Liu J, Zhu X (2017) Parkinson's disease-associated pathogenic VPS35 mutation causes complex I deficits. Biochim Biophys Acta Mol Basis Dis 1863, 2791-2795.

[32] Tang FL, Liu W, Hu JX, Erion JR, Ye J, Mei L, Xiong WC (2015) VPS35 deficiency or mutation causes dopaminergic neuronal loss by impairing mitochondrial fusion and function. Cell Rep 12, 1631-1643.

[33] Wang W, Wang X, Fujioka H, Hoppel C, Whone AL, Caldwell MA, Cullen PJ, Liu J, Zhu X (2016) Parkinson's disease-associated mutant VPS35 causes mitochondrial dysfunction by recycling DLP1 complexes. Nat Med 22, 54-63.

[34] Funayama M, Ohe K, Amo T, Furuya N, Yamaguchi J, Saiki S, Li Y, Ogaki K, Ando M, Yoshino H, Tomiyama H, Nishioka K, Hasegawa K, Saiki H, Satake W, Mogushi K, Sasaki R, Kokubo Y, Kuzuhara S, Toda T, Mizuno Y, Uchiyama Y, Ohno K, Hattori N (2015) CHCHD2 mutations in autosomal dominant late-onset Parkinson's disease: A genome-wide linkage and sequencing study. Lancet Neurol 14, 274-282.

[35] Huang X, Wu BP, Nguyen D, Liu YT, Marani M, Hench J, Benit P, Kozjak-Pavlovic V, Rustin P, Frank S, Narendra DP (2018) CHCHD2 accumulates in distressed mitochondria and facilitates oligomerization of CHCHD10. Hum Mol Genet 27, 3881-3900.

[36] Mao C, Wang H, Luo H, Zhang S, Xu H, Zhang S, Rosenblum J, Wang Z, Zhang Q, Tang M, Shepard MJ, Wang X, Wang Y, Zhuang Z, Shi C, Xu Y (2019) CHCHD10 is involved in the development of Parkinson's disease caused by CHCHD2 loss-of-function mutation p.T61I. Neurobiol Aging 75, 38-41.

[37] Matsumine H, Saito M, Shimoda-Matsubayashi S, Tanaka $\mathrm{H}$, Ishikawa A, Nakagawa-Hattori Y, Yokochi M, Kobayashi T, Igarashi S, Takano H, Sanpei K, Koike R, Mori H, Kondo T, Mizutani Y, Schaffer AA, Yamamura
Y, Nakamura S, Kuzuhara S, Tsuji S, Mizuno Y (1997) Localization of a gene for an autosomal recessive form of juvenile Parkinsonism to chromosome 6q25.2-27. Am J Hum Genet 60, 588-596.

[38] Kitada T, Asakawa S, Hattori N, Matsumine H, Yamamura Y, Minoshima S, Yokochi M, Mizuno Y, Shimizu N (1998) Mutations in the parkin gene cause autosomal recessive juvenile parkinsonism. Nature 392, 605-608.

[39] Grunewald A, Kasten M, Ziegler A, Klein C (2013) Nextgeneration phenotyping using the parkin example: Time to catch up with genetics. JAMA Neurol 70, 1186-1191.

[40] Sarraf SA, Raman M, Guarani-Pereira V, Sowa ME, Huttlin EL, Gygi SP, Harper JW (2013) Landscape of the PARKIN-dependent ubiquitylome in response to mitochondrial depolarization. Nature 496, 372-376.

[41] Winklhofer KF (2014) Parkin and mitochondrial quality control: Toward assembling the puzzle. Trends Cell Biol 24, 332-341.

[42] Shimura H, Hattori N, Kubo S, Yoshikawa M, Kitada T, Matsumine H, Asakawa S, Minoshima S, Yamamura Y, Shimizu N, Mizuno Y (1999) Immunohistochemical and subcellular localization of Parkin protein: Absence of protein in autosomal recessive juvenile parkinsonism patients. Ann Neurol 45, 668-672.

[43] Swatek KN, Komander D (2016) Ubiquitin modifications. Cell Res 26, 399-422.

[44] Shin JH, Ko HS, Kang H, Lee Y, Lee YI, Pletinkova O, Troconso JC, Dawson VL, Dawson TM (2011) PARIS (ZNF746) repression of PGC-1alpha contributes to neurodegeneration in Parkinson's disease. Cell 144, 689-702.

[45] Greene JC, Whitworth AJ, Kuo I, Andrews LA, Feany MB, Pallanck LJ (2003) Mitochondrial pathology and apoptotic muscle degeneration in Drosophila parkin mutants. Proc Natl Acad Sci U S A 100, 4078-4083.

[46] Palacino JJ, Sagi D, Goldberg MS, Krauss S, Motz C, Wacker M, Klose J, Shen J (2004) Mitochondrial dysfunction and oxidative damage in parkin-deficient mice. $J$ Biol Chem 279, 18614-18622.

[47] Yang Y, Gehrke S, Imai Y, Huang Z, Ouyang Y, Wang JW, Yang L, Beal MF, Vogel H, Lu B (2006) Mitochondrial pathology and muscle and dopaminergic neuron degeneration caused by inactivation of Drosophila Pink1 is rescued by Parkin. Proc Natl Acad Sci U S A 103, 10793-10798.

[48] Clark IE, Dodson MW, Jiang C, Cao JH, Huh JR, Seol JH, Yoo SJ, Hay BA, Guo M (2006) Drosophila pink1 is required for mitochondrial function and interacts genetically with parkin. Nature 441, 1162-1166.

[49] Park J, Lee SB, Lee S, Kim Y, Song S, Kim S, Bae E, Kim J, Shong M, Kim JM, Chung J (2006) Mitochondrial dysfunction in Drosophila PINK1 mutants is complemented by parkin. Nature 441, 1157-1161.

[50] Valente EM, Bentivoglio AR, Dixon PH, Ferraris A, Ialongo T, Frontali M, Albanese A, Wood NW (2001) Localization of a novel locus for autosomal recessive early-onset parkinsonism, PARK6, on human chromosome 1p35-p36. Am J Hum Genet 68, 895-900.

[51] Valente EM, Abou-Sleiman PM, Caputo V, Muqit MM, Harvey K, Gispert S, Ali Z, Del Turco D, Bentivoglio AR, Healy DG, Albanese A, Nussbaum R, GonzalezMaldonado R, Deller T, Salvi S, Cortelli P, Gilks WP, Latchman DS, Harvey RJ, Dallapiccola B, Auburger G, Wood NW (2004) Hereditary early-onset Parkinson's disease caused by mutations in PINK1. Science 304, 11581160 . 
[52] Aerts L, Craessaerts K, De Strooper B, Morais VA (2015) PINK1 kinase catalytic activity is regulated by phosphorylation on serines 228 and 402. J Biol Chem 290, 2798-2811.

[53] Okatsu K, Oka T, Iguchi M, Imamura K, Kosako H, Tani N, Kimura M, Go E, Koyano F, Funayama M, ShibaFukushima K, Sato S, Shimizu H, Fukunaga Y, Taniguchi H, Komatsu M, Hattori N, Mihara K, Tanaka K, Matsuda N (2012) PINK1 autophosphorylation upon membrane potential dissipation is essential for Parkin recruitment to damaged mitochondria. Nat Commun 3, 1016.

[54] Truban D, Hou X, Caulfield TR, Fiesel FC, Springer W (2017) PINK1, Parkin, and mitochondrial quality control: What can we learn about Parkinson's disease pathobiology? J Parkinsons Dis 7, 13-29.

[55] Narendra DP, Jin SM, Tanaka A, Suen DF, Gautier CA, Shen J, Cookson MR, Youle RJ (2010) PINK1 is selectively stabilized on impaired mitochondria to activate Parkin. PLoS Biol 8, e1000298.

[56] Pickrell AM, Youle RJ (2015) The roles of PINK1, parkin, and mitochondrial fidelity in Parkinson's disease. Neuron 85, 257-273.

[57] Rakovic A, Shurkewitsch K, Seibler P, Grunewald A, Zanon A, Hagenah J, Krainc D, Klein C (2013) Phosphatase and tensin homolog (PTEN)-induced putative kinase 1 (PINK1)-dependent ubiquitination of endogenous Parkin attenuates mitophagy: Study in human primary fibroblasts and induced pluripotent stem cellderived neurons. J Biol Chem 288, 2223-2237.

[58] Jin SM, Lazarou M, Wang C, Kane LA, Narendra DP, Youle RJ (2010) Mitochondrial membrane potential regulates PINK1 import and proteolytic destabilization by PARL. J Cell Biol 191, 933-942.

[59] Bonello F, Hassoun SM, Mouton-Liger F, Shin YS, Muscat A, Tesson C, Lesage S, Beart PM, Brice A, Krupp J, Corvol JC, Corti O (2019) LRRK2 impairs PINK1/Parkindependent mitophagy via its kinase activity: Pathologic insights into Parkinson's disease. Hum Mol Genet 28, 1645-1660.

[60] Wauters F, Cornelissen T, Imberechts D, Martin S, Koentjoro B, Sue C, Vangheluwe P, Vandenberghe W (2020) LRRK2 mutations impair depolarization-induced mitophagy through inhibition of mitochondrial accumulation of RAB10. Autophagy 16, 203-222.

[61] Soubannier V, McLelland GL, Zunino R, Braschi E, Rippstein P, Fon EA, McBride HM (2012) A vesicular transport pathway shuttles cargo from mitochondria to lysosomes. Curr Biol 22, 135-141.

[62] Soubannier V, Rippstein P, Kaufman BA, Shoubridge EA, McBride HM (2012) Reconstitution of mitochondria derived vesicle formation demonstrates selective enrichment of oxidized cargo. PLoS One 7, e52830.

[63] McLelland GL, Soubannier V, Chen CX, McBride HM, Fon EA (2014) Parkin and PINK1 function in a vesicular trafficking pathway regulating mitochondrial quality control. EMBO J 33, 282-295.

[64] Wang X, Winter D, Ashrafi G, Schlehe J, Wong YL, Selkoe D, Rice S, Steen J, LaVoie MJ, Schwarz TL (2011) PINK1 and Parkin target Miro for phosphorylation and degradation to arrest mitochondrial motility. Cell 147, 893-906.

[65] Hsieh CH, Shaltouki A, Gonzalez AE, Bettencourt da Cruz A, Burbulla LF, St Lawrence E, Schule B, Krainc D, Palmer TD, Wang X (2016) Functional impairment in miro degradation and mitophagy is a shared feature in familial and sporadic Parkinson's disease. Cell Stem Cell 19, 709-724.

[66] Morais VA, Haddad D, Craessaerts K, De Bock PJ, Swerts J, Vilain S, Aerts L, Overbergh L, Grunewald A, Seibler P, Klein C, Gevaert K, Verstreken P, De Strooper B (2014) PINK1 loss-of-function mutations affect mitochondrial complex I activity via NdufA10 ubiquinone uncoupling. Science 344, 203-207.

[67] Narendra D, Walker JE, Youle R (2012) Mitochondrial quality control mediated by PINK1 and Parkin: Links to parkinsonism. Cold Spring Harb Perspect Biol 4, a011338

[68] Bonifati V, Rizzu P, van Baren MJ, Schaap O, Breedveld GJ, Krieger E, Dekker MC, Squitieri F, Ibanez P, Joosse $\mathrm{M}$, van Dongen JW, Vanacore N, van Swieten JC, Brice A, Meco G, van Duijn CM, Oostra BA, Heutink P (2003) Mutations in the DJ-1 gene associated with autosomal recessive early-onset parkinsonism. Science 299, 256-259.

[69] Irrcher I, Aleyasin H, Seifert EL, Hewitt SJ, Chhabra S, Phillips M, Lutz AK, Rousseaux MW, Bevilacqua L, Jahani-Asl A, Callaghan S, MacLaurin JG, Winklhofer KF, Rizzu P, Rippstein P, Kim RH, Chen CX, Fon EA, Slack RS, Harper ME, McBride HM, Mak TW, Park DS (2010) Loss of the Parkinson's disease-linked gene DJ1 perturbs mitochondrial dynamics. Hum Mol Genet 19, 3734-3746.

[70] Burbulla LF, Song P, Mazzulli JR, Zampese E, Wong YC, Jeon S, Santos DP, Blanz J, Obermaier CD, Strojny C, Savas JN, Kiskinis E, Zhuang X, Kruger R, Surmeier DJ, Krainc D (2017) Dopamine oxidation mediates mitochondrial and lysosomal dysfunction in Parkinson's disease. Science 357, 1255-1261.

[71] Heo JY, Park JH, Kim SJ, Seo KS, Han JS, Lee SH, Kim JM, Park JI, Park SK, Lim K, Hwang BD, Shong M, Kweon GR (2012) DJ-1 null dopaminergic neuronal cells exhibit defects in mitochondrial function and structure: Involvement of mitochondrial complex I assembly. PLoS One 7, e32629.

[72] Van Goethem G, Dermaut B, Lofgren A, Martin JJ, Van Broeckhoven C (2001) Mutation of POLG is associated with progressive external ophthalmoplegia characterized by mtDNA deletions. Nat Genet 28, 211-212.

[73] Luoma P, Melberg A, Rinne JO, Kaukonen JA, Nupponen NN, Chalmers RM, Oldfors A, Rautakorpi I, Peltonen L, Majamaa K, Somer H, Suomalainen A (2004) Parkinsonism, premature menopause, and mitochondrial DNA polymerase gamma mutations: Clinical and molecular genetic study. Lancet 364, 875-882.

[74] Davidzon G, Greene P, Mancuso M, Klos KJ, Ahlskog JE, Hirano M, DiMauro S (2006) Early-onset familial parkinsonism due to POLG mutations. Ann Neurol 59, 859-862.

[75] Hudson G, Chinnery PF (2006) Mitochondrial DNA polymerase-gamma and human disease. Hum Mol Genet 15 Spec No 2, R244-252.

[76] Luoma PT, Eerola J, Ahola S, Hakonen AH, Hellstrom O, Kivisto KT, Tienari PJ, Suomalainen A (2007) Mitochondrial DNA polymerase gamma variants in idiopathic sporadic Parkinson disease. Neurology 69, 1152-1159.

[77] Eerola J, Luoma PT, Peuralinna T, Scholz S, PaisanRuiz C, Suomalainen A, Singleton AB, Tienari PJ (2010) POLG1 polyglutamine tract variants associated with Parkinson's disease. Neurosci Lett 477, 1-5.

[78] Anvret A, Westerlund M, Sydow O, Willows T, Lind C, Galter D, Belin AC (2010) Variations of the CAG trinucleotide repeat in DNA polymerase gamma (POLG1) is 
associated with Parkinson's disease in Sweden. Neurosci Lett 485, 117-120.

[79] Chan SS, Copeland WC (2009) DNA polymerase gamma and mitochondrial disease: Understanding the consequence of POLG mutations. Biochim Biophys Acta 1787, 312-319.

[80] Copeland WC, Longley MJ (2003) DNA polymerase gamma in mitochondrial DNA replication and repair. Scientific WorldJournal 3, 34-44.

[81] Longley MJ, Prasad R, Srivastava DK, Wilson SH, Copeland WC (1998) Identification of 5'-deoxyribose phosphate lyase activity in human DNA polymerase gamma and its role in mitochondrial base excision repair in vitro. Proc Natl Acad Sci U S A 95, 12244-12248.

[82] Kiferle L, Orsucci D, Mancuso M, Lo Gerfo A, Petrozzi L, Siciliano G, Ceravolo R, Bonuccelli U (2013) Twinkle mutation in an Italian family with external progressive ophthalmoplegia and parkinsonism: A case report and an update on the state of art. Neurosci Lett 556, 1-4.

[83] Vandenberghe W, Van Laere K, Debruyne F, Van Broeckhoven C, Van Goethem G (2009) Neurodegenerative Parkinsonism and progressive external ophthalmoplegia with a Twinkle mutation. Mov Disord 24, 308-309.

[84] LaVoie MJ, Hastings TG (1999) Dopamine quinone formation and protein modification associated with the striatal neurotoxicity of methamphetamine: Evidence against a role for extracellular dopamine. J Neurosci 19, 1484-1491.

[85] Larsson NG, Clayton DA (1995) Molecular genetic aspects of human mitochondrial disorders. Annu Rev Genet 29, 151-178.

[86] Zsurka G, Peeva V, Kotlyar A, Kunz WS (2018) Is there still any role for oxidative stress in mitochondrial DNAdependent aging? Genes (Basel) 9, 175.

[87] Hallberg BM, Larsson NG (2011) TFAM forces mtDNA to make a U-turn. Nat Struct Mol Biol 18, 1179-1181.

[88] Grunewald A, Rygiel KA, Hepplewhite PD, Morris CM, Picard M, Turnbull DM (2016) Mitochondrial DNA depletion in respiratory chain-deficient Parkinson disease neurons. Ann Neurol 79, 366-378.

[89] Chen C, Vincent AE, Blain AP, Smith AL, Turnbull DM, Reeve AK (2019) Investigation of mitochondrial biogenesis defects in single substantia nigra neurons using post-mortem human tissues. Neurobiol Dis 134, 104631.

[90] Giannoccaro MP, La Morgia C, Rizzo G, Carelli V (2017) Mitochondrial DNA and primary mitochondrial dysfunction in Parkinson's disease. Mov Disord 32, 346-363.

[91] Dolle C, Flones I, Nido GS, Miletic H, Osuagwu N, Kristoffersen S, Lilleng PK, Larsen JP, Tysnes OB, Haugarvoll K, Bindoff LA, Tzoulis C (2016) Defective mitochondrial DNA homeostasis in the substantia nigra in Parkinson disease. Nat Commun 7, 13548.

[92] Bender A, Krishnan KJ, Morris CM, Taylor GA, Reeve AK, Perry RH, Jaros E, Hersheson JS, Betts J, Klopstock T, Taylor RW, Turnbull DM (2006) High levels of mitochondrial DNA deletions in substantia nigra neurons in aging and Parkinson disease. Nat Genet 38, 515-517.

[93] Gaare JJ, Nido GS, Sztromwasser P, Knappskog PM, Dahl O, Lund-Johansen M, Maple-Grodem J, Alves G, Tysnes OB, Johansson S, Haugarvoll K, Tzoulis C (2018) Rare genetic variation in mitochondrial pathways influences the risk for Parkinson's disease. Mov Disord 33, 1591-1600.

[94] Pirooznia SK, Yuan C, Khan MR, Karuppagounder SS, Wang L, Xiong Y, Kang SU, Lee Y, Dawson VL, Dawson TM (2020) PARIS induced defects in mitochondrial biogenesis drive dopamine neuron loss under conditions of parkin or PINK1 deficiency. Mol Neurodegener 15, 17.

[95] Stevens DA, Lee Y, Kang HC, Lee BD, Lee YI, Bower A, Jiang H, Kang SU, Andrabi SA, Dawson VL, Shin JH, Dawson TM (2015) Parkin loss leads to PARIS-dependent declines in mitochondrial mass and respiration. Proc Natl Acad Sci U S A 112, 11696-11701.

[96] Safdar A, Little JP, Stokl AJ, Hettinga BP, Akhtar M, Tarnopolsky MA (2011) Exercise increases mitochondrial PGC-1alpha content and promotes nuclear-mitochondrial cross-talk to coordinate mitochondrial biogenesis. J Biol Chem 286, 10605-10617.

[97] Kuroda Y, Mitsui T, Kunishige M, Shono M, Akaike M, Azuma H, Matsumoto T (2006) Parkin enhances mitochondrial biogenesis in proliferating cells. Hum Mol Genet 15, 883-895.

[98] Rothfuss O, Fischer H, Hasegawa T, Maisel M, Leitner P, Miesel F, Sharma M, Bornemann A, Berg D, Gasser T, Patenge N (2009) Parkin protects mitochondrial genome integrity and supports mitochondrial DNA repair. Hum Mol Genet 18, 3832-3850.

[99] Matsuda N, Kitami T, Suzuki T, Mizuno Y, Hattori N, Tanaka K (2006) Diverse effects of pathogenic mutations of Parkin that catalyze multiple monoubiquitylation in vitro. J Biol Chem 281, 3204-3209.

[100] Pickrell AM, Huang CH, Kennedy SR, Ordureau A, Sideris DP, Hoekstra JG, Harper JW, Youle RJ (2015) Endogenous parkin preserves dopaminergic substantia nigral neurons following mitochondrial DNA mutagenic stress. Neuron 87, 371-381.

[101] West AP, Khoury-Hanold W, Staron M, Tal MC, Pineda CM, Lang SM, Bestwick M, Duguay BA, Raimundo N, MacDuff DA, Kaech SM, Smiley JR, Means RE, Iwasaki A, Shadel GS (2015) Mitochondrial DNA stress primes the antiviral innate immune response. Nature 520, 553-557.

[102] McArthur K, Whitehead LW, Heddleston JM, Li L, Padman BS, Oorschot V, Geoghegan ND, Chappaz S, Davidson S, San Chin H, Lane RM, Dramicanin M, Saunders TL, Sugiana C, Lessene R, Osellame LD, Chew TL, Dewson G, Lazarou M, Ramm G, Lessene G, Ryan MT, Rogers KL, van Delft MF, Kile BT (2018) BAK/BAX macropores facilitate mitochondrial herniation and mtDNA efflux during apoptosis. Science 359, eaao6047.

[103] Kim J, Gupta R, Blanco LP, Yang S, Shteinfer-Kuzmine A, Wang K, Zhu J, Yoon HE, Wang X, Kerkhofs M, Kang H, Brown AL, Park SJ, Xu X, Zandee van Rilland E, Kim MK, Cohen JI, Kaplan MJ, Shoshan-Barmatz V, Chung JH (2019) VDAC oligomers form mitochondrial pores to release mtDNA fragments and promote lupus-like disease. Science 366, 1531-1536.

[104] Bernardini JP, Brouwer JM, Tan IK, Sandow JJ, Huang S, Stafford CA, Bankovacki A, Riffkin CD, Wardak AZ, Czabotar PE, Lazarou M, Dewson G (2019) Parkin inhibits $\mathrm{BAK}$ and $\mathrm{BAX}$ apoptotic function by distinct mechanisms during mitophagy. EMBO J 38, e99916.

[105] Darios F, Corti O, Lucking CB, Hampe C, Muriel MP, Abbas N, Gu WJ, Hirsch EC, Rooney T, Ruberg M, Brice A (2003) Parkin prevents mitochondrial swelling and cytochrome $\mathrm{c}$ release in mitochondria-dependent cell death. Hum Mol Genet 12, 517-526.

[106] Berger AK, Cortese GP, Amodeo KD, Weihofen A, Letai A, LaVoie MJ (2009) Parkin selectively alters the intrinsic threshold for mitochondrial cytochrome c release. Hum Mol Genet 18, 4317-4328. 
[107] Sliter DA, Martinez J, Hao L, Chen X, Sun N, Fischer TD, Burman JL, Li Y, Zhang Z, Narendra DP, Cai H, Borsche M, Klein C, Youle RJ (2018) Parkin and PINK1 mitigate STING-induced inflammation. Nature 561, 258-262.

[108] Sarraf SA, Sideris DP, Giagtzoglou N, Ni L, Kankel MW, Sen A, Bochicchio LE, Huang CH, Nussenzweig SC, Worley SH, Morton PD, Artavanis-Tsakonas S, Youle RJ, Pickrell AM (2019) PINK1/parkin influences cell cycle by sequestering TBK1 at damaged mitochondria, inhibiting mitosis. Cell Rep 29, 225-235 e225.

[109] Gaidt MM, Ebert TS, Chauhan D, Ramshorn K, Pinci F, Zuber S, O’Duill F, Schmid-Burgk JL, Hoss F, Buhmann R, Wittmann G, Latz E, Subklewe M, Hornung V (2017) The DNA inflammasome in human myeloid cells is initiated by a STING-cell death program upstream of NLRP3. Cell 171, 1110-1124 e1118.

[110] Haque ME, Akther M, Jakaria M, Kim IS, Azam S, Choi DK (2020) Targeting the microglial NLRP3 inflammasome and its role in Parkinson's disease. Mov Disord 35, 20-33.

[111] Sarkar S, Malovic E, Harishchandra DS, Ghaisas S, Panicker N, Charli A, Palanisamy BN, Rokad D, Jin H, Anantharam V, Kanthasamy A, Kanthasamy AG (2017) Mitochondrial impairment in microglia amplifies NLRP3 inflammasome proinflammatory signaling in cell culture and animal models of Parkinson's disease. NPJ Parkinsons Dis 3, 30.

[112] Mouton-Liger F, Jacoupy M, Corvol JC, Corti O (2017) PINK1/parkin-dependent mitochondrial surveillance: From pleiotropy to Parkinson's disease. Front Mol Neurosci 10, 120.

[113] Zhou R, Yazdi AS, Menu P, Tschopp J (2011) A role for mitochondria in NLRP3 inflammasome activation. Nature 469, 221-225.

[114] Matheoud D, Sugiura A, Bellemare-Pelletier A, Laplante A, Rondeau C, Chemali M, Fazel A, Bergeron JJ, Trudeau LE, Burelle Y, Gagnon E, McBride HM, Desjardins M (2016) Parkinson's disease-related proteins PINK1 and parkin repress mitochondrial antigen presentation. Cell 166, 314-327.

[115] Matheoud D, Cannon T, Voisin A, Penttinen AM, Ramet L, Fahmy AM, Ducrot C, Laplante A, Bourque MJ, Zhu L, Cayrol R, Le Campion A, McBride HM, Gruenheid S, Trudeau LE, Desjardins M (2019) Intestinal infection triggers Parkinson's disease-like symptoms in Pink1(-/-) mice. Nature 571, 565-569.

[116] Roosen DA, Cookson MR (2016) LRRK2 at the interface of autophagosomes, endosomes and lysosomes. $\mathrm{Mol}$ Neurodegener 11, 73.

[117] Xilouri M, Brekk OR, Stefanis L (2016) Autophagy and alpha-synuclein: Relevance to Parkinson's disease and related synucleopathies. Mov Disord 31, 178-192.

[118] Gomez-Suaga P, Bravo-San Pedro JM, Gonzalez-Polo RA, Fuentes JM, Niso-Santano M (2018) ER-mitochondria signaling in Parkinson's disease. Cell Death Dis 9, 337.

[119] Guardia-Laguarta C, Area-Gomez E, Rub C, Liu Y, Magrane J, Becker D, Voos W, Schon EA, Przedborski S (2014) alpha-Synuclein is localized to mitochondriaassociated ER membranes. J Neurosci 34, 249-259.

[120] Paillusson S, Gomez-Suaga P, Stoica R, Little D, Gissen P, Devine MJ, Noble W, Hanger DP, Miller CCJ (2017) alpha-Synuclein binds to the ER-mitochondria tethering protein VAPB to disrupt $\mathrm{Ca}(2+)$ homeostasis and mitochondrial ATP production. Acta Neuropathol 134, 129-149.
[121] Tabata Y, Imaizumi Y, Sugawara M, Andoh-Noda T, Banno S, Chai M, Sone T, Yamazaki K, Ito M, Tsukahara K, Saya H, Hattori N, Kohyama J, Okano H (2018) T-type calcium channels determine the vulnerability of dopaminergic neurons to mitochondrial stress in familial Parkinson disease. Stem Cell Rep 11, 1171-1184.

[122] Lee KS, Huh S, Lee S, Wu Z, Kim AK, Kang HY, Lu B (2018) Altered ER-mitochondria contact impacts mitochondria calcium homeostasis and contributes to neurodegeneration in vivo in disease models. Proc Natl Acad Sci U S A 115, E8844-E8853.

[123] Ottolini D, Cali T, Negro A, Brini M (2013) The Parkinson disease-related protein DJ-1 counteracts mitochondrial impairment induced by the tumour suppressor protein $\mathrm{p} 53$ by enhancing endoplasmic reticulum-mitochondria tethering. Hum Mol Genet 22, 2152-2168.

[124] Ilijic E, Guzman JN, Surmeier DJ (2011) The L-type channel antagonist isradipine is neuroprotective in a mouse model of Parkinson's disease. Neurobiol Dis 43, 364-371.

[125] Guzman JN, Ilijic E, Yang B, Sanchez-Padilla J, Wokosin D, Galtieri D, Kondapalli J, Schumacker PT, Surmeier DJ (2018) Systemic isradipine treatment diminishes calciumdependent mitochondrial oxidant stress. J Clin Invest 128, 2266-2280.

[126] Zeuner KE, Schaffer E, Hopfner F, Bruggemann N, Berg D (2019) Progress of pharmacological approaches in Parkinson's disease. Clin Pharmacol Ther 105, 1106-1120.

[127] Saarni SI, Harkanen T, Sintonen H, Suvisaari J, Koskinen S, Aromaa A, Lonnquist J (2006) The impact of 29 chronic conditions on health-related quality of life: A general population survey in Finland using 15D and EQ-5D. Qual Life Res 15, 1403-1414.

[128] Xi Y, Feng D, Tao K, Wang R, Shi Y, Qin H, Murphy MP, Yang Q, Zhao G (2018) MitoQ protects dopaminergic neurons in a 6-OHDA induced PD model by enhancing Mfn2-dependent mitochondrial fusion via activation of PGC-1alpha. Biochim Biophys Acta Mol Basis Dis 1864, 2859-2870.

[129] Snow BJ, Rolfe FL, Lockhart MM, Frampton CM, O'Sullivan JD, Fung V, Smith RA, Murphy MP, Taylor KM, Protect Study Group (2010) A double-blind, placebo-controlled study to assess the mitochondriatargeted antioxidant MitoQ as a disease-modifying therapy in Parkinson's disease. Mov Disord 25, 1670-1674.

[130] Parkinson Study Group (2014) A randomized clinical trial of high-dosage coenzyme Q10 in early Parkinson disease: No evidence of benefit. JAMA Neurol 71, 543-552.

[131] Prasuhn J, Brüggemann N, Hessler N, Berg D, Gasser T, Brockmann K, Olbrich D, Ziegler A, König IR, Klein C, Kasten M (2019) An omics-based strategy using coenzyme Q10 in patients with Parkinson's disease: Concept evaluation in a double-blind randomized placebo-controlled parallel group trial. Neurol Res Pract $\mathbf{1}, 31$.

[132] Vos M, Esposito G, Edirisinghe JN, Vilain S, Haddad DM, Slabbaert JR, Van Meensel S, Schaap O, De Strooper B, Meganathan R, Morais VA, Verstreken P (2012) Vitamin $\mathrm{K} 2$ is a mitochondrial electron carrier that rescues pink1 deficiency. Science 336, 1306-1310.

[133] Wang Y, Hekimi S (2013) Mitochondrial respiration without ubiquinone biosynthesis. Hum Mol Genet 22, 4768-4783.

[134] Cerqua C, Casarin A, Pierrel F, Vazquez Fonseca L, Viola G, Salviati L, Trevisson E (2019) Vitamin K2 cannot substitute Coenzyme Q10 as electron carrier in the 
mitochondrial respiratory chain of mammalian cells. Sci Rep 9, 6553.

[135] Hertz NT, Berthet A, Sos ML, Thorn KS, Burlingame AL, Nakamura K, Shokat KM (2013) A neo-substrate that amplifies catalytic activity of parkinson's-disease-related kinase PINK1. Cell 154, 737-747.

[136] Tatton WG, Greenwood CE (1991) Rescue of dying neurons: A new action for deprenyl in MPTP parkinsonism. $J$ Neurosci Res 30, 666-672.

[137] Parkinson Study Group (1989) Effect of deprenyl on the progression of disability in early Parkinson's disease. $N$ Engl J Med 321, 1364-1371.

[138] Olanow CW, Rascol O, Hauser R, Feigin PD, Jankovic J, Lang A, Langston W, Melamed E, Poewe W, Stocchi F, Tolosa E, ADAGIO Study Investigators (2009) A double-blind, delayed-start trial of rasagiline in Parkinson's disease. $N$ Engl J Med 361, 1268-1278.

[139] Schapira AH (2011) Monoamine oxidase B inhibitors for the treatment of Parkinson's disease: A review of symptomatic and potential disease-modifying effects. CNS Drugs 25, 1061-1071.
[140] Parkinson Study Group (2020) Isradipine versus placebo in early Parkinson disease: A randomized trial. Ann Intern Med 172, 591-598.

[141] Bruggemann N, Klein C (2019) Will genotype drive treatment options? Mov Disord 34, 1294-1299.

[142] Noyce AJ, Bestwick JP, Silveira-Moriyama L, Hawkes CH, Giovannoni G, Lees AJ, Schrag A (2012) Metaanalysis of early nonmotor features and risk factors for Parkinson disease. Ann Neurol 72, 893-901.

[143] Ascherio A, Schwarzschild MA (2016) The epidmiology of Parkinson's disease: Risk factors and prevention. Lancet Neurol 15, 1257-1272.

[144] Rahman S, Copeland WC (2019) POLG-related disorders and their neurological manifestations. Nat Rev Neurol 15, 40-52.

[145] Martikainen MH, Ng YS, Gorman GS, Alston CL, Blakely EL, Schaefer AM, Chinnery PF, Burn DJ, Taylor RW, McFarland R, Turnbull DM (2016) Clinical, genetic, and radiological features of extrapyramidal movement disorders in mitochondrial disease. JAMA Neurol 73, 668-674. 